\title{
Social Media Strategy for Mass Rapid Transit Jakarta as a New Public Transport Project
}

\author{
Mareta Maulidiyanti ${ }^{*}$, Pijar Suciati $^{1}$ \\ ${ }^{1}$ Communication Department, Vocational Education Program, Universitas Indonesia \\ *Email: mareta.maulidiyanti@yahoo.com
}

\begin{abstract}
Mass Rapid Transit (MRT) Jakarta, a new mode of transportation in the city currently in its construction phase, will be operational by 2019. To open this new transportation mode for public use, its construction phase requires massive public communication to gain support and build public interest. One of PT MRT Jakarta's communication strategies is through digital channels: websites and social media. This study focuses on how digital communication programs, especially official social media, are used in public communication. This study adopts a descriptive qualitative approach and aims to determine whether the social media strategy undertaken by the company's corporate communications division follows social media optimization concepts. This research also uses interviews to collect data. From this study, we describe social media communication strategies especially through PT MRT Jakarta's Facebook, Instagram, and Twitter accounts to communicate the project as a new public transportation in the city. This research found that PT MRT Jakarta has already optimized social media for persuasive communication as an effort to build public support for and interest in the project. Facebook is used for contextual topics and provides detailed information, Instagram is used for good visualizations to encourage public interest, and Twitter is limited to sharing some short fragments of information. However, one of this study's limitations is that it has not seen the effectiveness of the content presented on public acceptance.
\end{abstract}

Keywords: public relations, MRT Jakarta, public transport, social media, communication, government communication

\section{Introduction}

Congestion in Jakarta has become an entrenched and unresolved problem. The current growth of motor vehicles is much higher than that of roads. Every day, more than 1,000 new motor vehicles are registered and join the streets of Jakarta (Jakarta Transportation Agency). It was predicted that Jakarta's traffic situation will be completely stalled by 2014 if the government fails to improve its mass transportation system (SITRAMP, 2004)

PT MRT Jakarta, a local enterprise owned by DKI Jakarta Province, is responsible for building and operating the city's Mass Rapid Transit (MRT). MRT Jakarta is considered a new mode of transportation which will launch in 2019. This project is fully funded by the government through a Japanese loan. Currently, MRT Jakarta is in its construction phase, which requires considerable public communication efforts to gain public support and interest.

Public relations for government programs include two main principles: the first involves reporting activities to the public, and the second entails encouraging public participation and support of government performance (Cutlip, 2009). This idea was supported by Lee, who said that the purpose of public relations in government is to fulfill its obligation to provide information to the community by considering their needs (Lee, Neeley, \& Stewart, 2012).

Goczol \& Scoubeau (2003) stated that in project communications, corporate communications should execute its communications strategy with specific objectives that are suitable to the project phase. PT MRT Jakarta currently runs a digital communication strategy with the specific objective to build public interest, as social media allows different ways to connect the government and citizens. The use of the Digital 2.0 concept highlights that governments use Internet-based communications for various needs such as recruitment, information dissemination, agencies (Chang \& Kannan, 2008), promoting transparency (Bertot \& Jargr, 2010), and encouraging public engagement (Dorris, 2008). Therefore, this concept completely fits MRT's digital 
communication strategy, as social media is more effective than traditional media in efficiently communicating government information to the public (Kingsley, 2010).

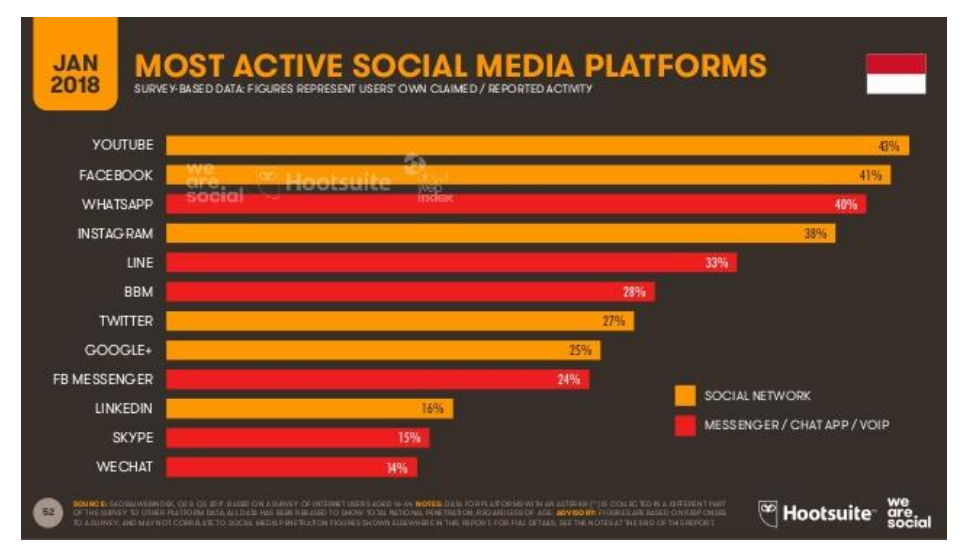

Figure 1. Most Active Social Media Platforms Source: Hootsuite

Figure 1 shows that Indonesia's most widely used communities are YouTube, Instagram, and Facebook. This study highlights how digital communication programs, especially social media, are used by MRT Jakarta to inspire public support and interest. This paper's results show how the company uses their Facebook and Instagram channels to communicate and build a positive image. It also identifies several suggestions for the company’s social media specialists for effective social media management.

\section{Literature Review}

\section{a. Public Relations}

Public relations (PR) always pertains to efforts in creating public understanding through knowledge (Frans, 2003). It is a form of communication that applies to all types of organizations, both commercial and noncommercial, and public (government) and private. Jefkins (Frans, 2003) defined PR as a planned and sustainable communication effort, maintaining goodwill and mutual understanding between an organization and its audience.

\section{b. New Communication Model}

The traditional communication model (Figure 2) shows one or more receivers interpreting the message according to their own experience and beliefs (Solomon, 2009). Social media stimulates receiver behavior including awareness, information search, opinion sharing, action DNA, and post action behavior (Mangold and Faulds, 2009). This communication process has significantly changed with the emergence of social media. Hence, social media platforms should be included in an organization's communication model as a potential tool for implementing its communications strategy. 


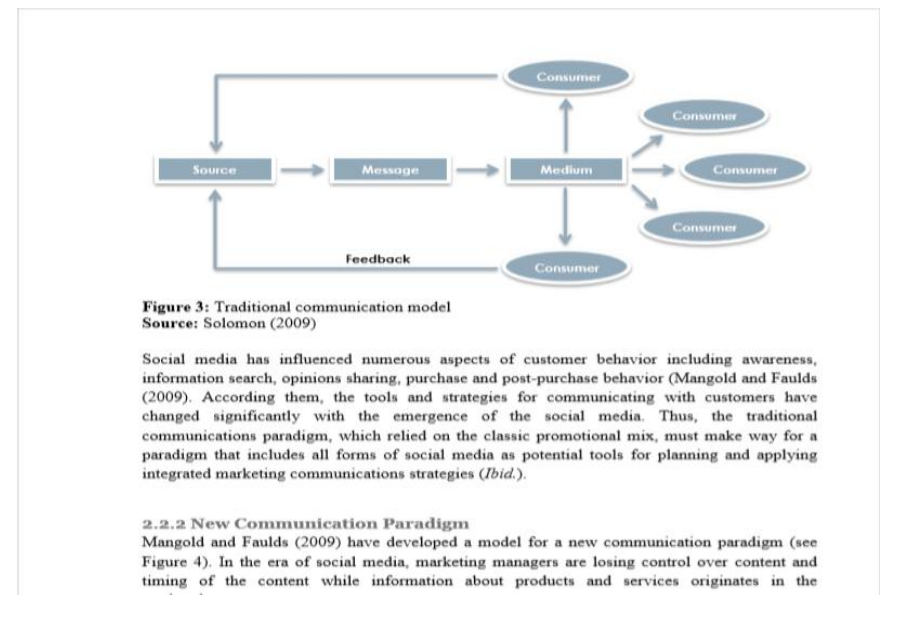

Figure 2. The Traditional Communication Model

Source: Adapted from Solomon (2009)

Figure 3 shows the two roles of social media in the marketplace (Mangold \& Faulds, 2009): first, to enable companies to communicate with their customers via blogs, Facebook, and other social networks, and second, to enable the public to communicate with one another and provide customers the opportunity to quickly spread the word to countless others within a short period.

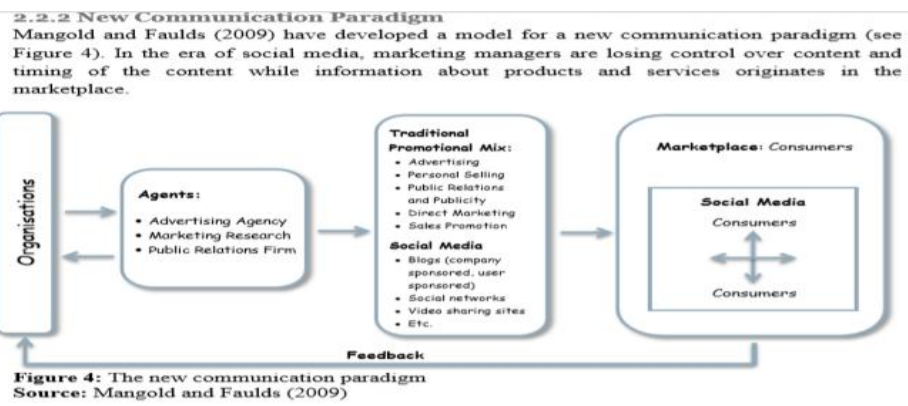

Figure 3. The New Communication Model

Source: Adapted from Mangold \& Faulds (2009)

\section{c. Social Media: Instagram, Twitter, and Facebook}

Social media is used to benefit public administration through increased citizen engagement (Agostino, 2013). It is used in several areas such as customer relationship management, marketing, and brand management for private companies (Trainor, Andzulis, Rapp, \& Agnihotri, 2014). However, Agostino (Agostino, 2013) argued that public-sector social media had not taken much of a role in connecting institutions to the public.

Palmer \& Koenig-Lewis (2009) divided social media into the following key categories:

a. Blogs-Online journals by individuals or firms often combined with audio or video podcasts

b. Social networks-Applications that allow users to build personal Web sites accessible to other users for personal content exchange and communication

c. Content communities-Websites for organizing and sharing particular types of content

d. Forums/bulletin boards-Sites for idea and information exchange, usually around special interests

e. Content aggregators-Applications that allow users to fully customize Web content

The young generation currently spends more time on Instagram than Facebook (Solomon, 2009) because young mobile users are extremely driven to take pictures using their mobile phones and instantly share them with others (Abbott, Donaghey, Hare, \& Hopkins, 2013). 


\section{d. Facebook}

Facebook can be used to create an account with a public or semipublic profile. Users have the option to display their friends' identities and share photos and activities (Palmer \& Koenig-Lewis, 2009). They can also publish information and share it with others, and they can also receive information about other peoples' lives. This leads to a form of collaboration that creates new content (Coulter \& Roggeveen, 2012). A study showed that Facebook is attractive to users because it builds on curiosity (we look at friends' photos and other people's profiles), enjoyment (we can communicate with other users), and excitement (we can send gifts and play games with other users) (Solomon, 2009). The average Facebook user is active for 32 minutes a day, and most log on to the site at least once every day (Park \& Cho, 2012). A 2009 study found that more than half of Facebook users have clicked on a company's Facebook page and that $16 \%$ of them had sent a message to that company (Solomon, 2009).

\section{e. Instagram}

Instagram is a mobile-based application that provides a photo-sharing social networking platform (Chante, Jessica, Lindsay, Tyler, \& Robert, 2014). This application enables users to take pictures, apply different manipulation tools to transform their photos, and instantly share them with friends (Hochman \& Schwartz, 2012). Launched in 2010, Instagram has grown rapidly, with more than 100 million users and approximately 4 billion photos uploaded and displayed (Abbott, Donaghey, Hare, \& Hopkins, 2013). In April 2012, Facebook acquired Instagram and its service for approximately $\$ 1$ billion in cash and stock. Instagram provides everything to attract customers on the world's most popular photo-sharing site. Once an image is shared, several standard social media behaviors can be employed to engage with the image (Miles, 2014). Around 75 million people use Instagram daily, and approximately 16 billion photos are uploaded and shared with other users (Smith, 2014). Instagram has a wide reach to the younger generation, and it appeals to diverse societies more prevailingly than other social networking services (Abbott, Donaghey, Hare, \& Hopkins, 2013).

The sharing of images rather than words alone has made communication with friends and broader groups of users who share similar interests more ideal, convenient, and fascinating (Bakhshi, Shamma, \& Gilbert, 2013). Because it performs like a social media channel that individuals, companies, vendors, and interest groups can easily join, pictures that are uploaded by any of them can be reposted, thus speeding up information dissemination (Chante, Jessica, Lindsay, Tyler, \& Robert, 2014). Instagram enhances online presence and identity by connecting the physical and digital realms (Abbott, Donaghey, Hare, \& Hopkins, 2013). PR professionals agree that Instagram is an effective way to build brand personality and loyalty. Social media often enables a company or brand to reach a different section of the public. Abbott, Donaghey, Hare, \& Hopkins, 2013 said that visual images tend to be more engaging than text alone.

According to Dan Frommer of Business Insider (2010, in Pijar Suciati, 2017) (Suciati, 2017) Instagram is an online photo-sharing, video-sharing, and social networking service that enables its users to take pictures and videos, apply digital filters to them, and share them on a variety of social networking services such as Facebook, Twitter, Tumblr, and Flickr.

\section{Methodology}

This study follows a descriptive approach. Descriptive research is a method whose variable indicators are the answers to verbal or written questions (Walizer \& Wienir, 1987). According to Neuman (Newman, 2003), descriptive research provides a complete picture of a situation, social phenomenon, or relationship. This method makes it possible to examine either one or more variables (Ruslan, 2003).

This research design is qualitative, which is implemented based on natural conditions and where informants provide data without any intervention (Kasali, 2008). The results of this qualitative research may be applied to similar situations and circumstances (Kountur, 2003). This study employs a case study strategy, which requires intensive research, uses some data sources, and is limited by time and research location. The case could be an organization, a group of people, a community, a phenomenon, a process, an issue, or a campaign program (Iriantara, 2004).

Primary data collection involved interviews with the PT MRT Jakarta corporate communications team. The interviews covered the process by which PT MRT Jakarta plans, implements, and evaluates their 
communications program. This interview also identified the kind of communication activities/campaigns the team conducts to gain public support.

Data Analysis: Qualitative content analysis was chosen to analyze textual content from the transcripts of interview discussions. Content analysis is a technique in which large amounts of data from interviews, field notes, and various types of sources are compressed into systematic and filtered text categories based on specific rules of coding (Steve, 2001). Previous studies have shown that this can enable the researcher to discover and describe the focus of individual, group, institutional, or social attention (Weber, 1990). In this study, the crucial process in content analysis is that categorization of some key words from the provided texts into certain themes.

\section{Results and Discussion}

PT MRT Jakarta's social media activities are managed by its corporate communications division under the corporate secretary. The discussion in this study focused on Instagram and Facebook.

\section{a. Facebook: MRT Jakarta}

MRT Jakarta uses Facebook to convey detailed and formal information. For example, the company regularly posts updates on the project's progress. Its Facebook page (MRT Jakarta), shown in Figure 4, is owned and managed by PT MRT Jakarta.

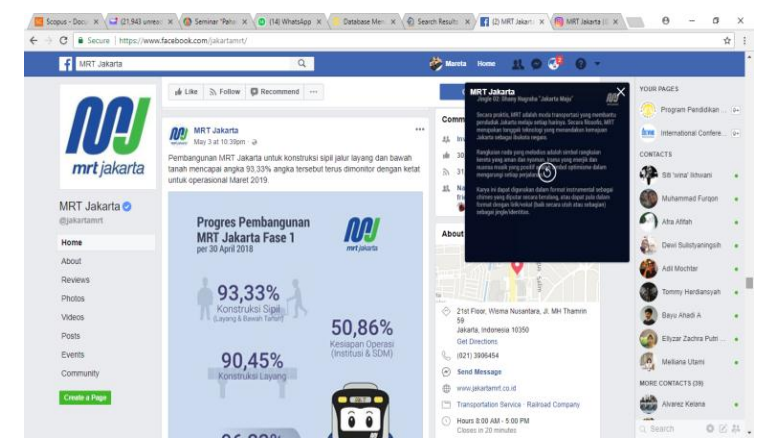

Figure 4. MRT Jakarta's Facebook Page for Project Progress

Besides project updates, PT MRT Jakarta uses Facebook to conduct surveys regarding the company's services. For example, the company surveys whether people need a special train for women (Figure 5). While MRT Jakarta's Facebook page has 31,151 followers, the response to every post remains very low, ranging from about 7 to 300 likes. The page's 229 reviews are considered very low relative to its follower count, showing that people are not interested in the content presented. Also, MRT Jakarta rarely responds to questions or comments posted by followers. Facebook links are also listed on the company's official website, www.jakartamrt.com.

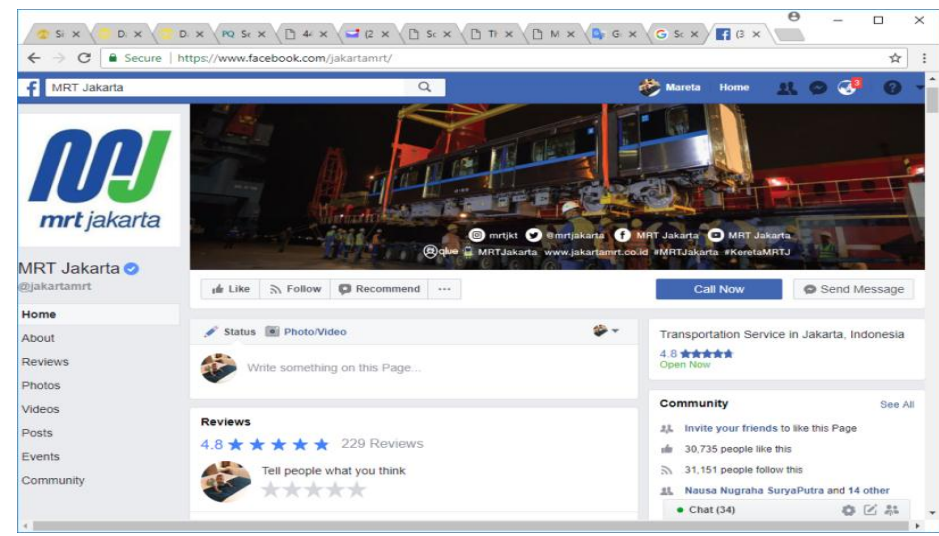




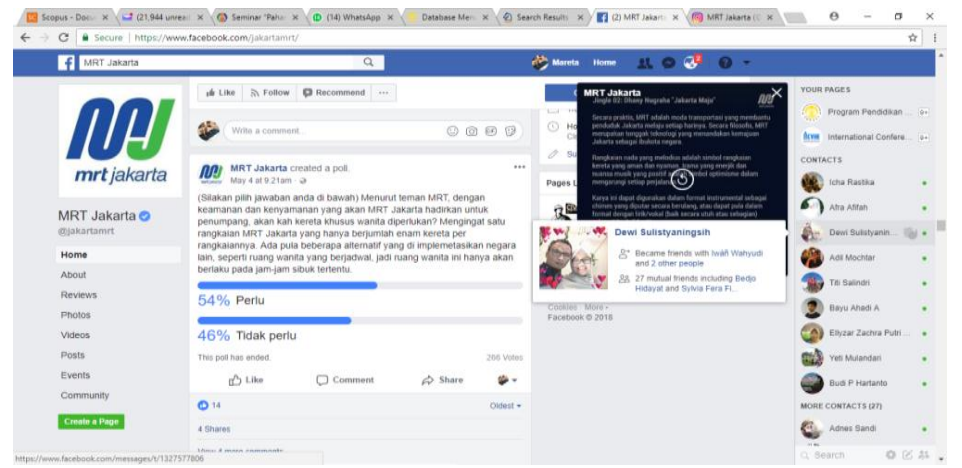

Figure 5. MRT Jakarta's Posts on Facebook

Facebook has various features that can be optimized, such as likes, comments, reviews, check-ins, and mentions.

We try to optimize the whole digital platform because we are believed that the current information dissemination is very fast through digital platform especially social media. (M. Akbar, Corporate Communications Specialist, PT MRT Jakarta)

Low responses to comments would lead to a drop in engagement. Schultz \& Peltier (2013) stated that one of social media's goals is for consumers to engage with the brand's content. Dholakia et al. said that a listening and response process through which consumers are engaged is required from a firm's content. Specifically, a firm's role in managing social communications may be either passive or active.

Consumer and firm engagement on social media consists of several phases (Dholakia, Blazevic, Wiertz, \& Algesheimer, 2009):

a. Consumer Engagement

Consumers react to content $\rightarrow$ Consumers comment on content $\rightarrow$ Consumers share content with others

$\rightarrow$ Consumers post user-generated content

b. $\quad$ Firm Engagement

Brand/company reacts to consumer content $\rightarrow$ Brand responds to consumer content $\rightarrow$ Brand shares consumer content with followers

However, the company have considerations when a comment needs to be repaid or not. This is to maintain a conducive and avoid miscommunication on Facebook Page. Although there are still some comments that missed to be replied (M. Akbar, Corporate Communications Specialist, PT MRT Jakarta)

The company's low response rate shows that its account still lacks firm engagement. While this may be a company strategy, the company needs to be careful in sorting out what content needs to be responded to and what does not. If uncontrolled, it will potentially diminish public engagement and open the possibility of a lower follower count.

\section{b. Instagram: @mrtjkt}

Unlike PT MRT Jakarta's Facebook page, its Instagram account focuses on visual and public education. For example, the company displays MRT facilities and profiles employees who work there, such as female drivers (Figure 6). This account also posts educational content about attitudes toward using public transport. Today, the @ mrtjkt account has 1,635 posts and more than 63,000 followers. 


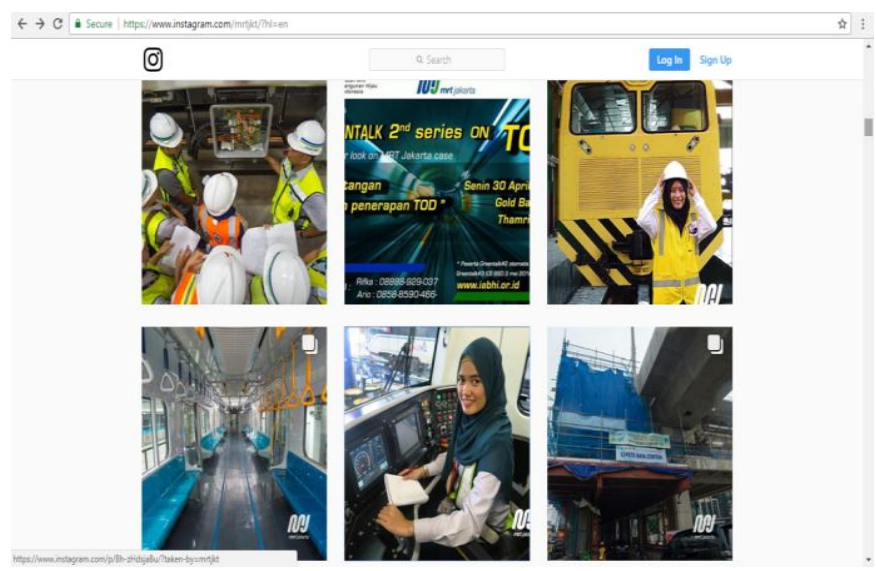

Figure 6. MRT Jakarta's Instagram Page Source: @mrtjkt Instagram Account

This account uses "MRT Friends" to greet its followers (Figure 7). Hashtags are also used to optimize topic engagement with the population. Just like on Facebook, this account also does not reply to followers' questions or comments. The company's public engagement on Instagram is quite good and better than that on its Facebook account. Public responses range from hundreds to thousands.
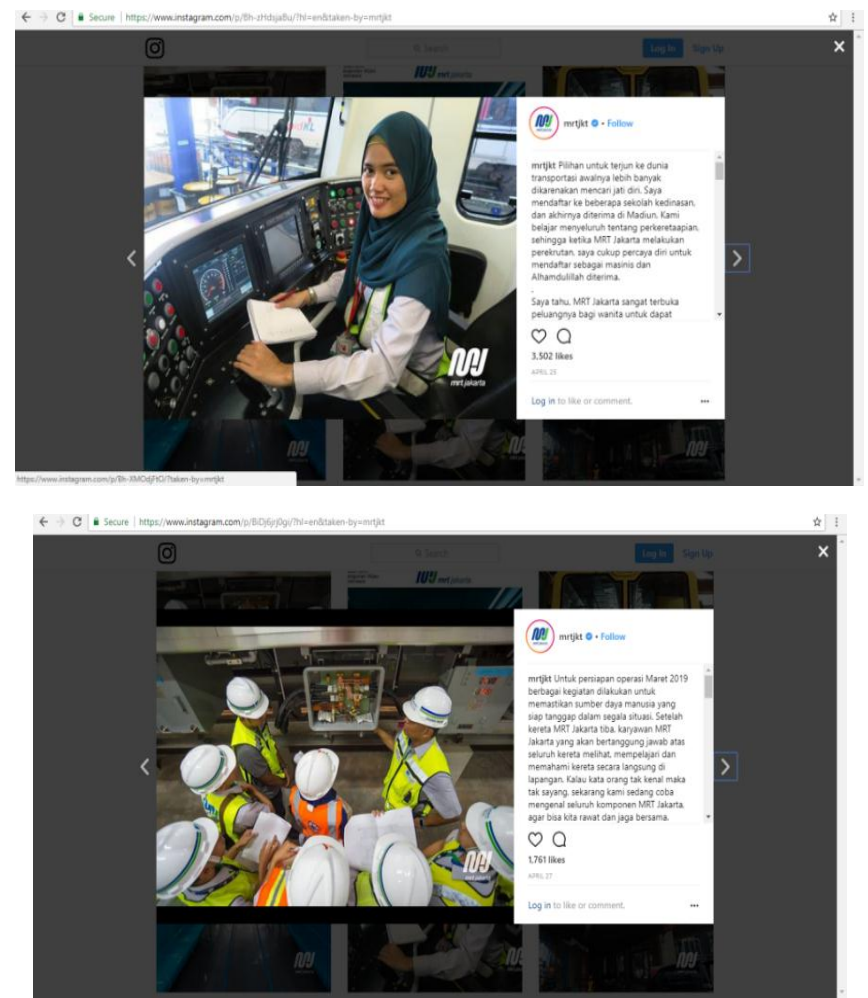

Figure 7. MRT Jakarta's Posts on Instagram Source: @mrtjkt Instagram Account 


\section{Conclusion}

From the discussion above, we can conclude the following:

1. PT MRT Jakarta, as a government company, understands that social media is an effective communication medium, even more than traditional media, for a certain target audience.

2. Corporate communications specialists have a good understanding of the advantages of each platform, as seen from the different types of content displayed.

3. PT MRT Jakarta has not been fully committed to responding to public reactions on its Facebook and Instagram posts. Thus, its consumer engagement does not match its firm engagement.

4. Facebook has features that can be optimized for better engagement.

\section{Acknowledgment}

I would like to express my gratitude to Prof. Sigit Pranowo Hadiwardoyo, DEA; Dr. Deni Danial Kesa; and Dr. Sri Rahayu for sharing their wisdom and knowledge to this research. I thank all my lecturer colleagues from the Communications Studies of Vocational Education Program of Universitas Indonesia who provided insight and expertize that greatly contributed to the research. This study was supported by PT MRT Jakarta as a research object. I am also grateful to Bapak Tubagus Hikmatullah, corporate secretary of PT MRT Jakarta, for allowing me to conduct an interview session with M. Akbar, their corporate communications specialist. Any errors and imperfections in this research are my own and should not tarnish the reputations of these esteemed persons.

\section{References}

Abbott, W., Donaghey, J., Hare, J., \& Hopkins, P. (2013). An Instagram is worth a thousand words: an industry panel and audience Q\&A. Library Hi Tech News, 30(7), 1-6. doi: 10.1108/LHTN-08-2013-0047

Agostino, D. (2013). Using social media to engage citizens: a study of Italian municipalities. Public Relations Review, 39(3), 232-234. doi: 10.1016/j.pubrev.2013.02.009

Bakhshi, S., Shamma, D. A., \& Gilbert, E. (2013). Faces engage us: photos with faces attract more likes and comments on Instagram.

Chang, A., \& P. K. Kannan. (2008). Leveraging Web 2.0 in Government. Retrieved from www.businessofgovernment

Chante, K., Jessica, C., Lindsay, B., Tyler, Q., \& Robert, P. D. (2014). Dermatology on Instagram. Dermatology Online Journal, 20(7), 1-6.

Coulter, K. S., \& Roggeveen, A. (2012). "Like it or not": consumer responses to word-of-mouth communication in on-line social networks. Management Research Review, 35(9), 878-899. doi: 10.1108/01409171211256587

Cutlip \& Center's Effective Public Relations. Front Cover. Glen M. Broom. (2009). Scott M. Cutlip, allen H. Center. Englewood Cliffs, United States of America: Prentice Hall.

Dholakia, U. M., Blazevic, V., Wiertz, C., \& Algesheimer, R. (2009). Communal service delivery: how customers benefit from participation in firm-hosted virtual P3 communities. Journal of service research, 12(2), 208-226. doi: $10.1177 / 1094670509338618$

Dorris, M. (2008). Service transformation in government. Executive Challenges: Today, Tomorrow, and Beyond, 1 (2008): 25.

Frans, J. (2003). Public relations. [Haris Munandar, penerjemah]. Jakarta: Erlangga.

Goczol, J., \& Scoubeau, C. (2003). Corporate communication and strategy in the field of projects. Corporate Communications: An International Journal, 8(1), 60-66. doi: 10.1108/13563280310458920

Hochman, N., \& Schwartz, R. (2012). Visualizing Instagram: tracing cultural visual rhytoms. In the proceedings of the workshop on Social Media Visualization in Conjunction with the 6th International AAAI Conference on Weblogs and Social Media.

Iriantara, Y. (2004). Dasar-dasar humas. Jakarta: Ghalia Indonesia.

Kasali, R. (2008). Riset Kualitatif dalam public relations \& marketing communications. Jakarta: Penerbit Bentang.

Kingsley, C. (2010). Making the most of social media: 7 lessons from successful cities. Retrieved from www.fels.upenn.edu/files/PP3 SocialMedia.pdf

Kountur, R. (2003). Metode penelitian:untuk Penulisan Skripsi Dan Tesis. Jakarta: Peberbit PPM.

Lee, M., Neeley, G. W., \& Stewart, K. (2012). The practice of government public relations. Pol. Sci. Faculty Publications.

Mangold, G. W., \& Faulds, D. J. (2009). Social Media: the new hybrid element of the promotion mix. Business Horizons (pp. 357-365). Kelley School of Business, Indiana University.

Miles, J. (2014). Instagram power: build your brand and reach more customers With the power of pictures. USA: McGrawHill Education. 
Beyond User Gaze: How Instagram Creates... (PDF Download Available). Available

Newman, L. (2003). Social research methods: Qualitatibe and quantitative approches. London: Allyn and Bacon.

Palmer, A., \& Koenig-Lewis, N. (2009). An Experiential, Social Network-Based Approach to Direct Marketing. Direct Marketing: An International Journal, 3(3), 162-176.

Park, H., \& Cho, H. (2012). Social network online communities: information sources for apparel shopping. Journal of Consumer Marketing, 29(6), 400-411. doi: 10.1108/07363761211259214 Retrieved from https://www.cision.com/us/2013/07/12-ways-social-media-is-changing-the-game-for-pr-pros/

Ruslan, R. (2003). Metode penelitian public relations dan komunikasi. Jakarta: Raja Grafindo Persada.

Schultz, D. E., \& Peltier, J. (2013). Social media's slippery slope: challenges, opportunities, and future research directions. Journal of research in interactive marketing, 7(2), 86-99. doi: 10.1108/JRIM-12-2012-0054

SITRAMP (2004). The study on integrated transportation master plan for Jabodetabek. Jakarta: National Development Planning Agency of the Republic of Indonesia \& Japan International Cooperation Agency.

Smith, A. (2014). Older adults and technology use [Online]. Washington: Pew Research Center.

Solomon, M. (2009). Customer behaviour: buying, having and being $\left(8^{\text {th }}\right.$ ed). Upper Saddle River, NJ: Pearson.

Steve (2001).

Suciati, P. (2017). Cultivation effect of tourism TV Program and influencer's Instagram account on the intention of traveling. Jakarta: Univeristas Muhamadiah Jakarta Proceeding.

Trainor, K. J., Andzulis, J., Rapp, A., \& Agnihotri, R. (2014). Social media technology usage and customer relationship performance: A capabilities-based examination of social CRM. Journal of Business Research, 67(6), 1201-1208. doi: 10.1016/j.jbusres.2013.05.002

Walizer, M. H., \& Wienir, P. L. (1987). Metode dan analisis penelitian: mencari hubungan, Jilid, 2. Jakarta: Erlangga.

Weber, R. P. (1990). Basic content analysis (2nd ed). Newbury Park, CA. 